\title{
An overview of post-divorce support for Muslim children in the context of South African Law, Islamic Law and the proposed 2010 Muslim Marriages Bill
}

\author{
Najma Moosa \\ Department of Private Law, \\ Faculty of Law, \\ University of the Western Cape, \\ Private Bag X17, Bellville, 7535, South Africa \\ E-mail: nmoosa@uwc.ac.za
}

\begin{abstract}
After 350 years of non-recognition, and following a protracted procedure, Muslim religious marriages and divorces are currently in the process of being directly and formally recognised in terms of South African Law. A 2010 'code' of Muslim Personal Law has been framed that can satisfy and synthesise both diverse Muslim (ideological) perspectives and the relevant constitutional commands (guarantees of religious freedom and equality to all South Africans). One of the key objectives of the proposed legislation is to regulate the consequences flowing from the termination of such marriages through divorce. My paper provides an analytical overview of the legal consequences flowing from a Muslim divorce in the context of South African Law, Islamic Law and the proposed 2010 Muslim Marriages Bill and focuses on the post-divorce support and position of minor and dependent Muslim children. As such, it is limited to the areas of guardianship, care, access and maintenance.
\end{abstract}

Keywords: Muslim; divorce; children; Islam; South Africa; guardianship; care; access; maintenance.

Reference to this paper should be made as follows: Moosa, N. (2013) 'An overview of post-divorce support for Muslim children in the context of South African Law, Islamic Law and the proposed 2010 Muslim Marriages Bill', Int. J. Liability and Scientific Enquiry, Vol. 6, Nos. 1/2/3, pp.27-41.

Biographical notes: Najma Moosa is a Professor of Law at Faculty of Law, University of the Western Cape. She is also the Dean of the Faculty of Law from 2002 to 2008. She is an advocate of the high court of South Africa. She is a member of the Project (59) Committee (Islamic Marriages and Related Matters) of the South African Law Reform Commission from 1999-2003.

\section{Introduction}

This paper provides an analytical overview of the legal consequences flowing from a Muslim divorce in the context of South African Law, Islamic Law and the proposed 2010 Muslim Marriages Bill, and focuses on the post-divorce support and position of minor and dependent Muslim children. As such, it is limited to the areas of guardianship, care, access and maintenance. 


\section{General context}

Muslims first arrived in South Africa more than 350 years ago. Although the South African Law Reform Commission (SALRC), as the governmental body responsible for considering law reform, some 25 years ago already started with an investigation into the possible recognition of their religious marriages, ${ }^{1}$ Muslim marriages and divorces are currently still not directly recognised in terms of South African Law. As a result, Muslim children were, until 2005, still stigmatised as 'illegitimate' even though their parents were married to each other in terms of Islamic Law. It is suggested that the status quo is exacerbated by the fact that in South African Muslim households the majority of Muslim women can be deemed to fall into the (ideological) category of conservative-Islamist Muslims most of whom are encouraged to be 'home-makers' and stay-at-home mothers while their husbands are primarily, though not necessarily, the sole breadwinners. Whilst theoretically well provided for during marriage, the nature of the Muslim marriage contract, which by default is deemed to be an ante-nuptial contract without any community of property and accrual, also means that the wife who did not work outside of the home, whether by choice or because she was not permitted to do so by her husband, and who is also not in possession of much self-generated or inherited wealth and education, is often left with few resources upon divorce. Given this reality in a negative economic climate which also affects ex-husbands who struggle to earn a decent income, the fact that her religious entitlement upon divorce is both limited and temporary, means that many South African Muslim women and their children will find themselves in dire straits and faced with the possibility of destitution when divorced since they cannot depend on their families (blood relatives) who no longer live as extended families but as modern nuclear families. Ex-husbands, more often than not, fail to pay maintenance for their children who are primarily left in the care of their mothers for periods much longer than envisioned by Islamic Law. Fearing possible destitution, the wife may as a measure of last resort turn to welfare ${ }^{2}$ but this provides little more than short term relief. It is contended that, given the practical reality of the South African context, recognition of Muslim marriages and divorces remains a necessary first step in solving this problem and that neither welfare organisations nor the broader Muslim community or even the State can or should be solely relied on or expected to carry this responsibility. As it is, South Africa currently does not have adequate funds to support those already in even more dire straits. ${ }^{3}$ While the wife is not required to make a contribution to the maintenance of children and even herself if she is in need thereof, this does not detract from the reality and the fact that women do so contribute, if not out of necessity then simply because they have the means and want to do so. ${ }^{4}$

It is in this context that Muslim marriages and related rights are in the process of being formally recognised and such recognition is proposed to take place by adjusting South African Law which, given the formal recognition of African customary marriages in 1998 and Civil Unions in 2006, is presently already recognised as a hybrid or mixed legal system. Following a protracted ${ }^{5}$ process, a statement or 'code' of Muslim Personal Law (MPL) ${ }^{6}$ has been framed that can satisfy and synthesise both diverse Muslim (ideological) perspectives and the relevant constitutional commands (guarantees of religious freedom and equality to all South Africans). One of the key objectives of the proposed legislation is to formally regulate the consequences flowing from the termination of Muslim marriages through divorce. The proposed legislation does not, however, reform divorce laws but accords with divorce rules developed by the Sunni 
schools of Islamic Law (Shari'a) ${ }^{7}$ as they are currently understood and implemented in practice in the Muslim world. ${ }^{8}$ It also does not spell out the Islamic Law detailed in this paper.

In South Africa, MPL is informally and unofficially regulated by essentially conservative male religious authorities (ulama) in quasi-judicial Muslim religious tribunals variously located in the provinces of South Africa. Their decisions, although morally binding, are not legally enforceable. Recalcitrant husbands, therefore, cannot be legally compelled to abide by the decisions of these tribunals or to give effect to the usually limited consequences flowing from their divorces. This has often resulted in Muslim women, who are often the first to be burdened with the duty of custody (care) of their children, being left with no other option but to seek recourse in terms of South African Law and to approach secular courts for relief. When provided by secular courts, relief is usually, although not necessarily, limited to the confines of Islamic Law.

\section{Constitutional, legislative and judicial contexts}

The current, and secular, South African Constitution ${ }^{9}$ does not constitutionalise the right to have MPL recognised. However, following the trend in Muslim countries, the only area of law that the Constitution expressly permits to be governed by religious law is family law ${ }^{10}$ and therefore expressly affords it constitutional protection, if recognised. As a result, a court cannot deem (discriminatory) religious family law as inherently in violation of the Constitution's freedom of religion clause (s 15 (1)). However, unlike the case in some Muslim countries, a court, relying on the provisions ${ }^{11}$ in the Constitution can require that MPL be consistent with it and its Bill of Rights and therefore in a 'subordinate' or 'inferior' position to other constitutional rights, especially equality (s 9) and human dignity (s 10).

The South African legislature ${ }^{12}$ and judiciary ${ }^{13}$, increasingly since the demise of apartheid and the introduction of our first democratic interim (1993) $)^{14}$ and current (1996) Constitutions, have, albeit indirectly and in a piecemeal fashion, recognised both monogamous and polygynous Muslim marriages and divorces by giving effect to some of the consequences flowing from the termination of Muslim marriages by death or divorce in order to provide relief to women and children. Recently this has also been extended by courts in several cases to include interim relief which, in terms of Rule 43 of the High Court Uniform Rules of Court (1999), ought only to be available to spouses in civil marriages. ${ }^{15}$ Courts have, however, not directly recognised Muslim marriages or resolved interpretational complexities in this regard. The judiciary maintains that it is the role of the legislature to do so.

Cognisant of the practical realities of non-recognition, the legislature in its turn hopes to change the status quo by formally giving direct statutory recognition to Muslim marriages. To this end, and in order to find a happy medium between the constitutional allowances therefore and the broad programme and trend of codification and reform in the Muslim world, from 2001 to 2010, three Draft Bills on the recognition of Muslim marriages and related matters have been proposed: the 2001 Islamic Marriages Bill (2001 IMB), the 2003 Muslim Marriages Bill (2003 MMB) and the 2010 Muslim Marriages Bill (2010 MMB) ${ }^{16}$ (essentially an amended version of the $2003 \mathrm{MMB}$ ). Since it is the latest published version, the $2010 \mathrm{MMB}(\mathrm{MMB})$ forms the focus of this paper. The MMB 
provisions pertaining to custody, guardianship and maintenance created the least contention and conform with Islamic Law in according rights and protection to women and children and regulating the corresponding duties of men.

\section{Religious context}

The topic of divorce in the primary sources and its later codification (Shari'a) is one that inevitably raises tensions because of real inequities which exist in the divorce law contained in these sources and which generally favour men over women. The later Islamic Law, although there are many areas of congruence, is also often at variance with the provisions of the earlier primary sources. While marriage and divorce in terms of the moral code of Islam generally emphasise the rights of women and corresponding duties of men, codes of MPL based on Islamic Law are biased towards men and place a stronger emphasis on their rights and corresponding duties of women. As far as divorce is concerned, in return for limited rights to, for example, maintenance and custody, the wife has to sacrifice almost all her rights expressly provided by Islam, for example, the right to equitable, honourable and kind treatment and mutual agreement and consultation in matters pertaining to personal law, and is placed in an inferior position.

In terms of Islamic Law, and premised on what today is deemed to be an outmoded and patriarchal Islamic ideal, especially in the current South African constitutional context, an economic superiority is attributed to Muslim husbands and fathers as a result of their being sole providers (breadwinners) and maintainers of dependant wives and children during the subsistence of their Muslim marriage(s). Notwithstanding that women are entitled to this support because they generally receive half the share of males in terms of the Islamic Law of inheritance, in terms of what is deemed to be a controversial Qur'anic injunction (Q.4:34) ${ }^{17}$ since it deems women to be dependents of economically superior men, the husband is duty bound to unilaterally support and maintain (nafaqa) his family. All that is expected as a quid pro quo from the wife, to justify her religious entitlement to such support, is that she in turn be a dutiful and obedient wife and good mother.

The husband's increased responsibilities are in turn also deemed to justify, on the one hand, his unilateral right to divorce and sole guardianship rights over the children and therefore their continued support upon divorce, and, on the other hand, the temporary support of his wife, and her limited right to custody of the children upon divorce.

If the husband cannot afford to or reneges on his duty to maintain the children, the mother is usually duty bound to do so in spite of the clear Qur'anic injunction (4:34) that she is not obliged to do so. Thus, in spite of the Islamic ideal, the South African reality is that Muslim children (and their mothers) are often not only inadequately maintained during marriage, but also unable to secure the limited financial resources that they are entitled to upon divorce, and even when religious tribunals have decided in their favour. While they await formal recognition of Muslim marriages and divorces, women are, therefore, often forced to seek relief for themselves and their children in terms of secular legislation and from the courts in South Africa. Given that approaching the courts is a costly affair, most of the cases where significant gains were made were test cases instituted on an ad hoc basis, and all initiated by women. While the precedents set ultimately benefit all women and their children, the successful party herself often gained very little real (financial) benefit. Cognisant that in terms of Islamic Law effective 
custody and guardianship ultimately remain vested in the ex-husband, whose financial and maintenance obligations to the ex-wife, though generous upon and during marriage, are severely curtailed upon and after divorce, the $\mathrm{MMB}^{18}$ regulates the usually limited consequences that flow from Muslim divorces and synthesises them with the provisions of South African Law. In doing so, it succeeds in making generous provision for children.

\section{The position of minors and dependent children}

\subsection{Guardianship (wilaya) ${ }^{19}$, care (custody or hadana) ${ }^{20}$, contact (or access)}

As indicated, in South Africa religious marriages, and therefore Muslim marriages, are currently recognised in terms of, and for the purposes set out in, several Acts. One of these is the Children's Act $(2005)^{21}$ which deals with the protection of the rights of a child. While of the main grievances against MPL are also directed against the laws relating to custody, guardianship and maintenance, a more radical example of reform includes the introduction of the concept of the 'best interests of the child' which enables women to retain custody of their children in the event of divorce even though they may have remarried, or even to retain custody for an extended period beyond that to which she would normally be entitled in terms of Islamic Law. ${ }^{22}$ It is, therefore, not surprising that, while this concept is also very much a part of South African $\mathrm{Law}^{23}$ it also plays a pivotal role in the MMB and legislation in other Muslim countries. South Africa has moved away from the concept of parental power or authority to parental rights and responsibilities (which include, caring for, maintaining contact with, acting as guardian for, and contributing to the maintenance of, the child). The term 'custody' has been replaced with the term 'care', and 'contact' is similar in meaning to 'access' (or visitation rights). Guardianship may also be co-exercised or shared by parents. ${ }^{24}$ In contrast to the Children's Act, Muslim countries still refer to concepts like 'custody' (which is also treated as a form of guardianship) and 'access' in their traditional meanings when referring to Islamic Law in state legislation pertaining to children. Since this is also the case in South Africa in both the $2010 \mathrm{MMB}$ and the Divorce Act (1979), ${ }^{25}$ these terms will be used in this paper for the sake of convenience.

Muslim children begin their first (natural) phase of life under female custody. Once this (limited) period terminates, they enter into a new phase under male guardianship. Having regard to both the Islamic and South African contexts, clause 10 (1) of the 2010 MMB clearly indicates that:

"[i]n making an order for the custody of, or access to a minor child, or in making a decision on guardianship, the court must, with due regard to Islamic law...Islamic norms and values, consider the welfare and best interests of the child."

Clause 10 (1) does not specify which parent, if any, gets awarded custody or/and guardianship nor does it stipulate the period of such custody or guardianship. It can, therefore, be inferred that either parent (therefore equal rights), both parents, neither parent, or someone other than the parents can be granted custody and/or guardianship since the term 'parent' is not used. While Islamic Law is not spelt out in the MMB, it is also important that any decision in terms of the MMB be guided by considerations and interpretations of Islamic Law. 
The Qur'an itself does not specify which parent gets custody of the children in the event of a divorce but it does appear to accept the father's perpetual (legal) right of guardianship. As indicated, although not without controversy, the latter is inferred from the Qur'anic (4:34) economic superiority attributed to Muslim men as maintainers of the family (and also by reference to the Prophet Muhammad himself ${ }^{26}$ ). Islamic jurisprudence recognises only the father as the natural guardian of his minor children and provides that the divorced fathers (and relatives) of children generally have both more (albeit supervisory) guardianship rights and more (financial) duties than their (caretaker) divorced mothers (and relatives). That women are usually attributed the initial (and, therefore, also limited) and natural role of custody of children, is clear from the Islamic Law definition which defines custody as

"...caring for the infant [of either sex] during the period when it cannot do without the women ${ }^{27}$ related to it in a prohibited $\left[{ }^{28}\right.$ ] degree [of marriage] who have the lawful right to bring it up."29

Islamic Law, rather than necessarily distinguishing between the terms 'custody' and 'guardianship', effectively treats custody as (a form of) guardianship. The mother's (right to and duty of) custody of her child during the early years of its life is, therefore, limited and is regarded as one (usually the first) of three categories of guardianship of the child. However, this does not mean that Muslim women and men have equal rights in this regard. Women are often also under the mistaken impression that they lose custody of their children if they divorce their husbands and it is also not uncommon for some Muslim men to capitalise on this ignorance and to use custody as a lever against their wives to discourage them from divorcing their husbands. The reality is that divorced mothers often find themselves having the actual (physical) responsibility of custody but few supervisory rights. The other two categories, namely, guardianship of the education and property of the child, are usually entrusted to the father (or other male relatives). ${ }^{30}$ Paradoxically, the fact that she may be financially competent and is allowed by Islam to control her own, and own, property unaided is of little consequence. The mother of the child, whether married to or divorced from the father, always has the first claim (and duty) to custody of her (infant) child. ${ }^{31}$ Although not explicitly stated and with due regard to the father's unilateral duty to support his children and the mother's initial right to custody, it seems that the MMB also supports the Islamic Law view that custody be awarded to the wife (mother) in the first instance, as well as in the case of interim custody. $^{32}$

Custody may, however, be entrusted to someone other than the mother, who may also be the father. In terms of the MMB, in the absence of both parents, a court must also consider Islamic Law when awarding custody or guardianship to anyone else. ${ }^{33}$

According to the Sunni schools of law the mother [or any other female custodian (hadina)] will lose her limited right to custody if she marries a man who is a stranger (that is, not a blood relative) to the child. There ought to be a close but different familial connection between the mother and the child and between the man and the child (which does not extend to the mother). ${ }^{34}$ This condition is based on a Prophetic tradition which effectively granted a divorced wife the custody of her son unless she marries. While this tradition is said to imply that a divorced woman loses this right if she marries any man who is not the father even if the man she marries is a blood relative of the child, it has not been interpreted so 'sweepingly' by jurists. ${ }^{35}$ It is suggested that this tradition also implies that a divorced woman, by the mere act of re-marrying, may lose custody of her 
child. Presumably, her marital duties towards her new husband will preoccupy all her time leaving her with no time to care for her children.

The above categories make it clear that Islamic Law separates the custody of the mother (to which she is entitled irrespective of her mainly Christian or Jewish (kitabi) religion in the case of inter-religious marriages) ${ }^{36}$ from the sole and legal guardianship of the father. The mother's custody (and regardless of whether or not she may want this role) is clothed as a 'right' but actually amounts to a 'duty'. It encompasses the daily grind of responsibility for and physical care of the child, in contrast to the more supervisory guardianship role of the father over the person, education and property of the child. In terms of Islamic Law and as is in fact legislated in some Muslim countries, parents, regardless of who may have custody, may not prevent each other from seeing their children. They are bound to give each other access. ${ }^{37}$ This is also the case in terms of the $\mathrm{MMB}^{38}$ with regard to both custody and guardianship.

\subsection{Periods of custody and guardianship}

The provisions of the MMB do not specify the periods of custody and guardianship and, therefore, guidance must be sought in Islamic Law rulings which may also vary according to the school of law. The mother's period of custody (form of guardianship) of her child, in respect of which there is no limitation in the Qur'an and Sunna, has been determined as a result of the ijtihad (independent reasoning or interpretation) of early jurists who also hold different views in this regard. According to these views, women are usually denied custody of their children beyond a certain age depending on the gender of the child and the school of law (madhhab) to which the family subscribes. The Hanbalite school does not distinguish on the basis of the sex of the child and rules that the mother's custody is from birth till 7 years, at which time the child may choose between his or her parents. The ruling of the Shafi'ite school is more complicated. Like the Hanbalites, it also does not make a distinction between the sexes while the child is in the custody of the mother, nor do these jurists set a definite term. The mother's custody is deemed to continue until the child reaches an age of discretion and is able to choose between the parents. However, the matter is not as clear cut as that. If the boy chooses his mother, he resides with her during the night but spends the day with his father (who is responsible for his education). The girl who chooses her mother resides with her for the duration of the mother's period of custody. The child who chooses both gets to spend time with the parents according to lots drawn by them. If the child remains silent (undecided?) on the matter, he/she stays with the mother. According to the Malikite school, the son stays with the mother from birth till puberty, and the daughter till she gets married. ${ }^{39}$ According to the Hanafite school, custody for both sexes starts at birth and ends for a son when he reaches an age where he is (independently) able to do certain basic things, such as, eat, dress and keep himself clean. While this age may range from seven to nine years, the mother's custody of her son (or that of any other caregiver of the boy) usually ends at seven years of age. The Hanifite jurists differ as regards the period of custody of a girl. The prevailing opinion is that it ends with her reaching puberty which may range from nine to eleven years. Others are of the opinion that she may stay with her mother or grandmother until the 'age of womanhood' but only until the age of puberty if she is in the custody of another female. ${ }^{40}$ While the terms 'womanhood' and 'puberty' are generally construed in secular parlance to have the same meaning, that is, when a girl 
starts to menstruate, Nasir ${ }^{41}$ highlights that this need not necessarily be the case since some women can menstruate at a very young age (and well before they can be considered to have reached majority or a marriageable age) while others do so at a much later age (well past their adolescence).

Some Muslim countries, for example, Tunisia and Turkey, have reformed their laws by increasing the respective ages and even go as far as equalising the rights of parents to custody and guardianship.

While Sunni jurists differ on the ages when the mother's (or other female's) custody of the children should terminate, they assumed that, after a limited period of time (custody) with their mothers, children of divorced (or widowed) women pass into the care of the father or nearest male agnate relative in the event of the father's death. ${ }^{42}$

The guardianship rights of the father have deprived a woman of the right to bring up her children as an equal parent. However, and with due regard to the fact that men who may be excellent caregivers may also suffer from gender stereotyping in matters pertaining to custody and guardianship, Muslim women who are forced to, or may even choose to, leave their children with their father upon divorcing him or re-marrying could view this 'freedom' from or 'rejection' of 'natural' parental responsibilities and duties as a re-balancing of priorities and a redressing of past inequalities rather than as discrimination in reverse, ${ }^{43}$ or even as some traditionalists would like them to believe, as being liberated from a burdensome role.

While there are variations in the laws pertaining to custody and guardianship of children, in recent years the rules relating to custody of the mother (and to a much lesser extent guardianship of the father) have been relaxed in most Muslim countries in favour of the mother, with the welfare or best interests ${ }^{44}$ of the child being the decisive factor.

\section{3 (Periods of) maintenance (nafaqa) ${ }^{45}$}

In terms of Islamic Law, nafaqa covers maintenance generally owed by a man to his dependants. It is also understood as such in terms of the $\mathrm{MMB}^{46}$ which expressly stipulates that the provisions of the Maintenance Act (1998) ${ }^{47}$ apply, 'with the changes required by the context', ${ }^{48}$ if a maintenance court makes a maintenance order. This means that a court must take into consideration the Islamic Law provisions in this regard and as outlined in the MMB. ${ }^{49}$ In a nutshell, upon the termination of his marriage, the obligations of a father with regard to his children do not also come to an end. In terms of the MMB, a father is obliged to maintain his daughters 'until they are married', ${ }^{50}$ and sons 'until they reach the age of majority or otherwise for the period that they are in need of support'. 51

In terms of Islamic Law a divorced (unmarried) daughter who is in need of support once again becomes the responsibility of the father until her re-marriage. The adult male child may, however, also be in need of further support, for example, due to a chronic illness or mental or physical handicap which prevents him from earning a living. ${ }^{52}$ Given the broader guardianship rights and duties of the father, he has to maintain the children during marriage and even if he is separated (divorced) from their mother or if the children live elsewhere or are in the custody of another person (including the mother). ${ }^{53}$ Accordingly, more generous provision is made for support of children in the MMB which stipulates that his duty to maintain children born of the marriage(s) continues when the marriage(s) ends and '...includes the provision of food, clothing, separate accommodation, medical care and education, ${ }^{54}$ 
In terms of Islamic Law, due regard must be had to the father's financial means and capacity (including the genuine effort he ought to make to ensure that he acquires the means to be able to earn a living) or incapacity (for example, due to a chronic illness) to provide maintenance. ${ }^{55}$ This is also reflected in the MMB where the amount of maintenance for which a father is responsible will vary from case to case and 'must be' determined in a 'fair and just ${ }^{56}$ manner and with due regard to 'his means' and the special 'need of support' for older male children ${ }^{57}$ and older daughters. This would, therefore, also preclude the child who is in possession of his/her own wealth. In terms of Islamic Law, indigent parents also have similar rights to maintenance from children who have the means to provide such support. ${ }^{58}$

As indicated in Section I, it is only since 2005 that Muslim children in South Africa are no longer labelled as 'legitimate' or 'illegitimate'. Their parents are referred to simply as being 'married' or 'unmarried' and the term 'children of unmarried parents' is used. In terms of South African Law a child is regarded as being born of married parents 'if the biological parents were legally married to each other at the time of the child's conception, or at his or her birth, or at any time between conception and birth' ${ }^{59}$ A practical issue that, therefore, raises its head concerns the question of legitimacy of a child conceived during marriage but where the ex-wife's pregnancy is only ascertained during the defined mandatory Qur'anic ${ }^{60}$ 'waiting' or 'probationary' period (idda) (lit. 'to count') which must be observed by the wife even after she has been irrevocably divorced. Technically, this means that the child will be born 'out of wedlock' but in reality it is assumed that the child is her husband's especially since she may also not re-marry during the idda period. This of course does not rule out the possibility of pregnancy resulting from a sexual encounter with somebody else. In the event of a divorce, the MMB clearly limits the husband's duty to support, and issues of interim custody or access, to a 'child born of the marriage ${ }^{61}$ Maintenance and guardianship of such children is, therefore, also not directly provided for in the proposed MMB. In the event of a dispute of this nature arising after an irrevocable separation, Islamic Law allows that the parentage (maternity and paternity) of children of spouses, besides being established through marriage, may also be established through acknowledgement by the father or evidence thereof (for example, through paternity testing or the witnessing of the birth by a midwife). ${ }^{62}$

Sunni jurists are unanimous ${ }^{63}$ that, following the birth of her child, a divorced mother may breastfeed her baby for the duration of the nursing ('fosterage') period (which is up to (but not necessarily) two years) ${ }^{64}$ regardless of whether she is irrevocably divorced from the child's father. She is entitled to separate remuneration while she breastfeeds her own child. ${ }^{65}$ This is also provided for in terms of the MMB. ${ }^{66}$ The mother's effort which goes into the process of bottle-feeding a child will presumably be calculated as part of her additional post-idda expenses, while the actual costs of bottle-feeding will form part of the general maintenance due to the child by the father whilst in the mother's custody and care. It is contended that she should also be compensated for bottle-feeding her child during the idda period. During the nursing period following an irrevocable divorce, the father must maintain and house both the child and mother and this is also provided for in terms of the MMB. ${ }^{67}$ The parents may also decide that the father employ a salaried wetnurse (or foster mother) to breastfeed the child if the mother is unable or unwilling to do so herself. ${ }^{68}$

It is clear that the areas of guardianship, care, access and maintenance in relation to children often overlap with each other and for this reason it is also very difficult 
to strictly separate the position of the mother (which is not the focus of this paper) from that of her children. For example, while maintenance for the child is theoretically generously provided by the father, such maintenance ought to be inextricably linked with that given to the mother during the post-divorce period that their children are in her custody, and this symbiosis ought to lead to an intended augmentation of the usually limited amount and period of post-divorce support for the mother. It is, however, contended that, with some exception, the inference that mothers may stand to substantially benefit through children in their care is currently unfounded in South Africa. Although the Islamic ideal, this is simply not a material reality for many South African Muslim women who, instead, often have to step into the shoes of the father when he reneges on his duties in this regard. It is, therefore, hoped that the provisions of the MMB will be able to rectify this.

In line with the trend already established by courts in terms of Rule 43 concerning interim maintenance, but more strictly in accordance with Shari'a, the MMB provides that, following the registration of an irrevocable divorce ${ }^{69}$ and after failed attempts at compulsory mediation, ${ }^{70}$ in the event of a dispute and before the adjudication thereof by the court, given the urgent nature of these cases, spouses may make an application to seek interim relief pending litigation (pendente lite) in matters pertaining to interim custody or access to minor children of the marriage or 'for the payment of maintenance, ${ }^{71}$ contribution to costs, ${ }^{72}$ and maintenance for the wife during the idda period. $^{73}$ I have emphasised in italics 'the payment of maintenance' to highlight the fact that, given the unilateral Islamic Law duty of the father to provide maintenance for his children, and the initial right of custody of the mother, it is contended that if a court grants the mother interim custody, the father is not only responsible for the child's maintenance, but also to remunerate the mother who has custody during this period, and further that this is separate from, and in addition to, the idda maintenance of the wife.

\section{Conclusions}

Acknowledging the differences that exist between the sources of Islamic Law, state legal systems in various Muslim countries have sought to exercise some, if not much, control over the consequences of an Islamic divorce. The trend of reform in Islamic Law of divorce has been through judicial regulation, and, although long overdue, South Africa is in the process of following suit with its proposed draft legislation which continues to be promoted and which, it is hoped, will be enacted into law by the end of 2012. The MMB has, through its provisions, ensured that the limited rights guaranteed to children in terms of Islamic Law will be utilised optimally, and in so doing will allow Islamic Law rights to be upheld secularly with the force of law and with the cooperation of religious authorities. If the legislature fails to enact the MMB, it will mean that the children and their mothers for whom the MMB is intended to be of most benefit, the status quo of non-recognition will remain. Current generations of Muslim men and women live with the reality that as citizens they can have recourse to secular laws of the state and its courts, with or without a recognised MPL, when seeking redress for the hardships caused by the consequences of the non-recognition of their Islamic marriages and divorces. 


\section{Acknowledgements}

I wish to acknowledge, with thanks, the support of Mr. SR. Allcock of Juta \& Co, the publisher, and Professor J. Heaton, the commissioning editor, of a forthcoming book provisionally titled The Law of Divorce and Dissolution of Life Partnerships in South Africa (2013), to re-use and condense a portion of my contributing chapter titled 'The dissolution of a Muslim marriage' (especially the section dealing with consequences) for purposes of this conference and re-publication as part of its proceedings and elsewhere. I also thank the South African National Research Foundation and the University of the Western Cape for their research support.

\section{Notes}

1 For a detailed history of the engagement of the SALRC with Islamic Law, see Moosa, N. (2011) Unveiling the Mind. The Legal Position of Women in Islam - A South African Context, 2nd ed., pp.143-162, Juta, Cape Town [hereinafter Moosa, 2011].

2 See Toffar, A.K. (1993) Administration of Islamic Law of Marriage and Divorce in South Africa, pp.262-264, Durban-Westville.

3 See Skelton, A. et al. (2010) Family Law in South Africa (see note 149), p.351, Oxford Uni. Press, Cape Town [hereinafter Skelton, 2010].

4 A recent study conducted among a sample of 295 Muslim women in the Western Cape, one of nine provinces in South Africa, suggests '...that the division of labour and the relative financial contributions of Muslim wives and husbands may be shifting to the point that men are no longer primarily the sole breadwinners in Muslim households...' [Shaikh, S. et al. (2011) 'Submission. the research report South African Muslim women: sexuality, marriage and reproductive choices', paper submitted to the Minister of Justice and Constitutional Development, p.4.

5 See supra note 1.

6 MPL refers to the religion (divine) based private or family law and pertains to, among other things, marriage, divorce, maintenance, the custody and guardianship of children, and succession (inheritance) [Moosa, (2011), supra note 1 at 10,82]. The basic prescriptions of Islamic Law (Shari'a), as established in the primary sources of Islam, namely, the Qur'an (holy book of Islam) and Sunna (Hadith or traditions of Prophet Muhammad based on the Qur'an), from which Islamic Law is ultimately derived and on which it is based, regulate in the main matters of MPL. To provide legislative guidance for solutions to new problems, two further secondary 'sources' were developed from and added to the two primary sources by human endeavour, namely, ijma (consensus of opinion of either legal scholars or the community) and qiyas (analogical deductions, through independent reasoning or ijtihad and ijma) [Moosa, (2011), supra note 1 at 9,30].

7 The elaborate Shari'a divorce rules were developed by four male jurists, namely, Imams (lit. leaders) Abu Hanifa, Malik, Shafi'i and Hanbal, who founded the four traditionalist Sunni schools (madhhabs or versions) of law, namely, Hanafi, Maliki, Shafi' $i$ and Hanbali, named after them [Moosa, (2011), supra note 1 at 56]. This paper focuses on these Sunni (as opposed to Shi'ite) schools and, where relevant, on the differences of opinion among its founding jurists, even within the same school. South African born Muslims and their ulama are essentially followers of the Hanafi and Shafi' $i$ schools [Moosa, (2011), supra note 1 at 151].

8 Since the 1950s there was an increase in the number of states that adopted their own codes of MPL. The law was codified, amended or reformed based on re-interpretation of the Shari'a. Today almost every Arab state has its own personal law code, with Shari'a still forming the basis of MPL, albeit reformed, codified and applied by modern legal structures [Moosa, (2011), supra note 1 at 68-69 and 74-75]. See infra note 22. 
9 Constitution of the Republic of South Africa, 1996 [hereinafter current Constitution].

10 Section 15 (3)(a) allows for the enactment of legislation recognising '(i) marriages concluded under...a system of religious, personal or family law; or (ii) systems of personal or family law... adhered to by persons professing a particular religion'.

11 Section 15 (3)(b) and s 39 (3) (interpretation clause).

12 Various Acts, or sections thereof, expressly provide that they apply to de facto monogamous or polygynous religious marriages. For a detailed list see Heaton, J. (2010) South African Family Law, 3rd ed., p.232, LexisNexis, Durban [hereinafter Heaton, 2010] and Rautenbach, C. et al. (Eds.) (2010) 'Religious legal systems: law of marriage - Muslim Law', Introduction to Legal Pluralism in South Africa, 3rd ed., p.192, LexisNexis, Durban [hereinafter Rautenbach, 2010].

13 In addition to the clear statutory recognition referred to in supra note 12 , the courts have also interpreted the wording of several other statutory provisions to extend to Muslim marriages. Apart from this, the courts have, in several other decisions which did not pertain to interpretation of legislation, also extended limited recognition to Muslim marriages. For a detailed list of these decisions [see Heaton, (2010), supra note 12 at 232-235; Rautenbach (2010), supra note 12 at 198-203; Moosa, (2011), supra note 1 at 147-149]. See also Mbatha et al. (2007) 'Culture and religion' in Bonthuys, E and Albertyn, C (Eds.): Gender, Law and Justice, pp.162, 171-172, Juta, Cape Town.

14 Constitution of the Republic of South Africa, Act 200 of 1993.

15 Rule 43 makes it possible for either spouse in a civil marriage to apply for several forms of interim relief for himself or herself or their children in matters pertaining to maintenance, care of and contact with a child, and a contribution to the costs of legal fees, whilst an instituted matrimonial action is pending. For detail on these and other unreported cases [see Rautenbach, (2010), supra note 12 at 203; Heaton, (2010), supra note 12 at 235; Skelton, (2010), supra note 3 at 197 (see note 18)].

16 The 2001 IMB and 2003 MMB are, respectively, appended as Annexures B (pp.134-151) and A (pp.110-133) to the SALRC Project 59 Report on Islamic Marriages and Related Matters, (Pretoria, July 2003) which is available at http://www.justice.gov.za/salrc/reports/r_prj59_2003jul.pdf. The text of the $2010 \mathrm{MMB}$ (as approved and recommended by the SALRC in 2003 and adapted by the Department of Justice and Constitutional Development) is available at http://www.justice.gov.za/legislation/bills/2010_muslim-marriages-bill.pdf (all accessed 20 March 2013).

17 The Qur'anic references in this paper refer to the translation by Yusuf Ali (1946). The first number in the citation refers to the number of the chapter (surah) and the second number indicates the verse (ayat). See Moosa (2011, supra note 1 at 21-23).

For further reference to Q.4:34 and a discussion of the controversies pertaining both to this verse and to Q.2:228 see Moosa, (2011, supra note 1 at 26, 46, 106-107, note 99). See also Nasir, JJ. (2009) 'The status of women under Islamic Law and Modern Islamic Legislation', Arab and Islamic Laws Series, 3rd ed., Vol. I, p.105, Brill NV, Leiden [hereinafter Nasir, 2009], see also infra note 60. For inheritance law see Moosa, N. (1991) Comparative Study of the South African and Islamic Law of Succession and Matrimonial Property with Especial Attention to the Implications for the Muslim Woman, unpublished LLM thesis, Uni. of the Western Cape, Bellville, p.135 [hereinafter Moosa, 1991].

18 Clauses 10 and 11

19 See Moosa, N. (1998) 'Muslim personal laws affecting children: diversity, practice and implications for a new children's code for South Africa', South African Law Journal, pp.115, 479 [hereinafter Moosa, 1998], for earlier research in this regard and WLUML (2006) Knowing Our Rights: Women, Family, Laws and Customs in the Muslim World, 3rd ed., pp.337-341, Women Living Under Muslim Laws, London [hereinafter WLUML, 2006]. 
20 Literally, means 'caring' in Arabic. A female custodian of a child is referred to as a 'hadina' whilst a male custodian is referred to as a 'hadini', Nasir (2002) 'The Islamic Law of personal status', Arab and Islamic Laws Series, 3rd ed., Vol. XXIII, p.263, Kluwer Law Int., The Hague [hereinafter Nasir, 2002].

21 See the definition of marriage in s 1 (1) of the Children's Act 38 of 2005 [hereinafter Children's Act], supra note 12 and supra text to note 59.

22 See supra note 8.

23 See, for example, s 28 (2) of the current Constitution (supra note 9) and s 9 of the Children's Act (supra note 21).

24 See Chapter 1, section 1 (interpretation) and Chapter 3, section 18 (2) (parental responsibilities and rights) and section 18 (3) (shared guardianship) of the Children's Act (supra note 21).

25 Although the Divorce Act 70 of 1979 refers to these terms, it does not define them and therefore needs to be aligned with the Children's Act (supra note 21).

26 This is based on an inference drawn from an extract in the Prophet's last sermon given in 632 $\mathrm{AD}$ on his farewell pilgrimage (hajj) to the holy city of Mecca, to the effect that the child belongs to the (father's) bed on which it was born (rather than to the mother who gave birth to him or her) [Moosa (2011), supra note 1 at 41].

27 My emphasis added in italics. This refers to the mother of the child in the first instance and other female custodians. In the event that the mother dies or is disqualified from custody (she loses her limited right to custody if she is unable (or unwilling) to take care of her children), there is great variation in the rulings of the schools of law as to who replaces her in this regard. The Hanafi school, for example, rules that since the mother has first claim to custody, her relatives, rather than those on the side of her child's father, should be given preference (Nasir, (2009), supra note 17 at 187]. See infra note 42.

28 Prohibited degrees refer to those persons related by blood, marriage or fosterage (breastfeeding or nursing) who are forbidden to marry each other.

29 Nasir (2009, supra note 17 at 186).

30 Nasir (2002, supra note 20 at 158).

31 Id at 159.

32 Clauses $10(1)$ and (2) read with clauses 11 (2)(c)(ii) and $9(3)(\mathrm{g})(\mathrm{i})$ (interim custody).

33 Clause $10(3)$.

34 Moosa 2011, supra note 1 at 42.

35 Nasir 2009, supra note 17 at 193.

36 In South Africa inter-religious marriages, although only permitted for Muslim men, do occur among Muslims of both sexes. The polgynous marriages of a Muslim man may be entered into with non-Muslim kitabi women who, because they practise a monotheistic religion, do not have to convert to Islam. A Muslim woman may, however, only marry a Muslim man and only one at a time [Moosa, (2011), supra note 1 at 33]. Whilst the Hanafis consider apostasy a sufficient reason to deny a woman her right (and duty) to custody, the schools of law are not unanimous that apostasy of the mother should necessarily be a ground for disqualifying her from her right to custody [Nasir, (2002), supra note 20 at 164]. It appears that on the basis of the Islamic law presumption that a child follows the father's religion, that a non-Muslim mother is not easily granted custody by courts [WLUML, (2006), supra note 19 at 340]. See supra note 26. I am uncertain of the gender-neutrality of this disqualification with regard to a father who has renounced Islam, although it can be inferred from the fact that the same general conditions of eligibility, which include religion, that apply to a female custodian in this regard, apply to male custodians [Nasir, (2002), supra note 20 at 164-165). Nasir (2009, supra note 17 at 196) also indicates that if the male custodian (hadini) of a ward is a male agnate (through the male line of the father's family), he must be of the same religion as his ward, because his right to custody is based on his right to inheritance. However, a non-agnate relative is not required to be of the same faith as the child because in this case his right to custody is based on a kinship within the prohibited degree (and not on inheritance). 
37 Nasir (2009, supra note 17 at 198-201).

38 Clause 10 (2) read together with clause 10 (1).

39 See text to supra note 50 where in terms of clause 11 (2)(b)(i) of the MMB the father is also obliged to provide maintenance for daughters until they marry.

40 Nasir (2002, supra note 20 at 171).

41 Nasir (2009, supra note 17 at 203).

42 See supra note 27 with regard to what happens in the case of the mother's death. See Nasir (2009, supra note 17 at 188) and Moosa (1998, supra note 19 at 488-490 and 492) for detail on this aspect of MPL affecting children. See supra note 36.

43 Moosa, N. (1996) An Analysis of the Human Rights and Gender Consequences of the New South African Constitution and Bill of Rights with Regard to the Recognition and Implementation of Muslim Personal Law (MPL), unpublished LLD dissertation, p.49, Bellville. Uni. of the Western Cape [hereinafter Moosa, 1996].

44 Judges have made use of independent reasoning (ijtihad) to do so, especially in cases where there was no clear Qur'anic guidance or where the schools of law had expressed divergent views on the topic. See WLUML (2006, supra note 19 at 344-345), Nasir (2009, supra note 17 at 191) and Moosa (1996, supra note 43 at 26-27).

45 Maintenance usually includes, among other things, the provision of food, clothing and lodging but may not be limited thereto. In determining such maintenance due consideration is given to various factors, for example, the means or income of parents, their social standing, and their standard and cost of living.

46 Clauses 11 (2)(a) and (b).

47 Act 99 of 1998.

48 Clause $11(1)$.

49 Clause $11(2)$

50 Clause $11(2)(\mathrm{b})(\mathrm{i})$.

51 Clause 11 (2)(b)(ii).

52 Nasir 2002, supra note 20 at 177.

53 See Nasir (2009, supra note 17 at 183 regarding maintenance and id at 198-201) regarding access.

54 Clause $11(2)(\mathrm{c})(\mathrm{iv})$.

55 Nasir (2002, supra note 20 at 174-176, 178-179).

56 Clause $11(3)$.

57 Clause $11(2)(b)(i i)$.

58 Nasir (2002, supra note 20 at 174-176, 178-179).

59 S 20 of the Children's Act and in terms of which the term 'marriage' is broadly defined to include Muslim marriages (s 1)) (supra note 21). See Boezaart, T. (2010) Law of Persons, 5th ed., pp.94-95, Juta, Claremont.

60 Q.2:228. See also supra note 17.

61 My emphasis added in italics. See, respectively, clauses 11 (2)(c)(iv) and 9 (3)(g)(i). See also text to supra note 54 .

62 Nasir 2002, supra note 20 at 145, 150). See also s 21 of the Children's Act (supra note 21) and text to supra note 59 .

63 Nasir (2009, supra note 17 at 183-184).

64 Q. 31:14 and Q.2:233.

65 Q. 65.1.

66 Clause 11 (2)(c)(iii).

67 Clause $11(2)(\mathrm{c})(\mathrm{ii})$. 
68 See Q.2:233; Q.65:1 and 6.

69 In the form of a repudiation (talaq) (clause 9(3)(g)) or judicial divorce (faskh) (clauses 9(5)(b) and (c)).

70 See clause 12 (1) together with clauses 4, 9(3)(e) and 9(5)(b).

71 Clause 9(3)(g)(i).

72 Clause $9(3)(\mathrm{g})(\mathrm{ii})$.

73 Clause $9(3)(\mathrm{g})(\mathrm{iii})$. 